\title{
High in-hospital mortality due to COVID-19 in a community hospital in Spain: a prospective observational study
}

Joan Carles Trullàs ( $\sim$ jctv5153@comg.cat )

Hospital d'Olot https://orcid.org/0000-0002-7380-3475

Eva Ruiz

Hospital de Olot

Clara Weisweiler

Universitat de Girona

Gemma Badosa

Hospital de Olot

Alba Serra

Hospital de Olot

Hugo Briceño

Hospital de Olot

Sílvia Soler

Hospital de Olot

Josep Bisbe

Hospital de Olot

Research article

Keywords: COVID-19, SARS virus, severe acute respiratory syndrome, coronavirus, community hospital, hospital mortality

Posted Date: July 14th, 2020

DOI: https://doi.org/10.21203/rs.3.rs-39421/v1

License: (c) (i) This work is licensed under a Creative Commons Attribution 4.0 International License.

Read Full License 


\section{Abstract}

Background To describe the clinical characteristics and outcome of patients with COVID-19 in a community hospital in Spain

Methods Prospective, single-centre case series of the first 100 consecutive hospitalized patients with COVID-19 at a community hospital in Spain, from March 16 to April 20, 2020. Demographics, comorbidities, clinical presentation, radiologic and laboratory findings, treatment and clinical outcome were collected.

Results Of the 100 patients included in the study, the median age (IQR; range) was 75 years (20; 28-96) and $52 \%$ were men. The most common comorbidities were hypertension (63\%), diabetes $(22 \%)$ and cardiovascular diseases (28\%). The most common symptoms were fever $(80 \%)$, cough (69\%), fatigue $(59 \%)$ and dyspnea (52\%) and $64 \%$ had respiratory insufficiency. Bilateral interstitial infiltrates (65/100, $65 \%)$ and bilateral vertical "B-kerley" lines $(38 / 46,82.6 \%)$ were the most common imaging manifestations in chest radiographs and lung ultrasound, respectively. All patients received supplementary oxygen, 69 $(69 \%)$ received medical treatment (the most common regimen being hydroxychloroquine plus azithromycin in 66 patients) and 12\% were treated with glucocorticoids. During hospitalization, 26 patients $(26 \%)$ died, $10(10 \%)$ were transferred to ICU and $64(64 \%)$ were discharged at home. Mortality or ICU admission was more frequent in advanced age and with comorbidities.

Conclusions This case series provides clinical characteristics and outcome of consecutively hospitalized patients with COVID-19 admitted to a community hospital in Spain. The majority were old patients, with comorbidities and in-hospital mortality was high (26\%).

\section{Background}

A cluster of pneumonia of unknown origin was identified in Wuhan, China, in December 2019. The disease named coronavirus disease 2019 (COVID-19) was caused by a novel coronavirus termed SARSCoV-2 and was declared an international public health emergency by the World Health Organization (WHO). In the WHO European Region, COVID-19 surveillance was implemented on January 2020 and nine European countries reported 47 cases, being France and Germany the countries with more confirmed cases. At that time only two cases from Spain were reported [1]. Since then, larger series of cases from different countries (China, United States and Italy) and different settings (from long-term care facilities to ICU) have been reported with some differences in demographics, comorbidities and mortality rates [2-4].

In this study, we describe the clinical features and outcome of the first 100 sequentially admitted patients with laboratory-confirmed COVID-19 to the Hospital de Olot i comarcal de la Garrotxa (HOCG), a community hospital in Spain.

\section{Methods}




\section{Study design}

Prospective and observational study of the first patients with COVID-19 diagnosed in a community hospital in Spain.

\section{Scope and study population}

The study was performed in "La Garrotxa" a rural region that belongs to the province of Girona (Spain) and has a total population of 57,590 inhabitants with remarkable aging ( $20 \%$ have an age equal to or more than 65 years old). The HOCG regional hospital has 136 hospital beds ( 64 for acute patient care and 72 for chronic care). Under normal conditions, no Intensive Care Unit (ICU) beds are available, but exceptionally, operating room resuscitation has been enabled to attend to a maximum of 4 critical patients.

\section{Study period}

The study started on March 16, 2020 after the admission of the first case of COVID-19 in our hospital. The study will end once the pandemic is over (to be defined) but for the present analysis we included the first 100 cases.

\section{Inclusion and exclusion criteria}

This study included all consecutive patients admitted to our hospital with a diagnosis of COVID-19. Only those patients who do not consent to participate in the study were excluded.

\section{COVID-19 definition}

In order to diagnose a COVID-19 case, the criteria defined by the "Spanish Ministry of Health" on March 2020 were followed. For the present study, only those cases with laboratory confirmation (PCR positive to any of the SARS-CoV-2 genes) were included.

\section{Data collection and study variables}

The following variables were collected: demographics, cardiovascular risk factors, comorbidities, clinical presentation, analytical and radiological abnormalities (chest radiography, computed tomography -CTand/or lung ultrasound -LUS-) and treatment. The comorbidities and one-year risk of death was calculated using the PROFUND score, that includes demographic, clinical, laboratory, social and functional variables, and establishes 4 levels of risk of death: low, intermediate, high and very high [5]. LUS abnormalities were classified using a score similar to that of Soldati et al [6]. Finally, we collected information about the outcome after admission (discharge, death, or transfer to the ICU).

\section{Statistical analysis}

Categorical variables are expressed as number and percentage and quantitative variables as median and interquartile range [IQR]. The Chi-square $(\chi 2)$ or the Fisher exact tests were used to compare qualitative variables, and the Student's T test to compare quantitative variables (the Mann-Whitney U test for non- 
normally distributed variables). A 2-sided a of less than 0.05 was considered statistically significant. Analyses were performed with the software SPSS version 20.0 (SPSS, Inc., Chicago, Illinois, USA).

\section{Ethical considerations}

The Ethics Committee of the "Hospital Universitari Dr. Josep Trueta, Girona (Spain)" approved the study protocol and informed consent was obtained from all participating subjects.

\section{Results}

As of April 20, 2020, there were 100 patients consecutively hospitalized with COVID-19 whose age distribution and baseline characteristics are summarized in Fig. 1 and Table 1, respectively. Most patients had advanced age with a median (range) of 75 (28-96) years old. There was a high burden of comorbidities (the most frequent being hypertension (63\%), diabetes mellitus (22\%) and cardiovascular diseases $(28 \%)$ ) and a high risk for mortality according to the PROFUND score. In contrast, few patients were active smokers or had chronic respiratory diseases and only one patient had HIV infection. Table 2 shows clinical, radiological and laboratory findings. The most frequent symptoms were fever $(80 \%)$, cough $(69 \%)$, fatigue $(59 \%)$ and dyspnea (52\%) but other symptoms such as anorexia (36\%) or diarrhea $(21 \%)$ were not uncommon. The most common findings on chest radiographs were bilateral interstitial infiltrates (65\%) and no radiographic abnormality was found in 11 patients $(11 \%)$. Only two chest CT were performed showing pulmonary thromboembolism in both cases. Lung ultrasound (LUS) was performed in 46 patients and only 3 patients (6.5\%) had no abnormalities. The most frequent LUS abnormalities were bilateral vertical "B-kerley" lines in 38 patients (82.6\%). Treatment during hospital admission is shown in Table 3. All patients received oxygen and one third required high concentrations. One third of patients received only symptomatic treatment and $69 \%$ received medical treatment, the most frequent being the combination of hydroxychloroquine and azithromycin (66 cases). No medicationrelated adverse event was observed. 
Table 1

Demographics and baseline characteristics of 100 patients with COVID-19 admitted to the HOCG Total Alive and discharged Death or ICU p value

\begin{tabular}{|c|c|c|c|c|}
\hline Number of patients & 100 & 64 & 36 & - \\
\hline Age (years) & 75 [20]; 28-96 & 73 [27]; 28-96 & 79 [19]; 46-93 & 0.003 \\
\hline$<50$ years & $9(9 \%)$ & $8(13 \%)$ & $1(3 \%)$ & 0.02 \\
\hline $50-69$ years & $30(30 \%)$ & $21(33 \%)$ & $9(25 \%)$ & \\
\hline $70-79$ years & $23(23 \%)$ & $15(23 \%)$ & $8(22 \%)$ & \\
\hline $80-89$ years & $31(31 \%)$ & $17(27 \%)$ & $14(39 \%)$ & \\
\hline$\geq 90$ years & $7(7 \%)$ & $3(5 \%)$ & $4(11 \%)$ & \\
\hline Male gender & $52(52 \%)$ & $31(48 \%)$ & $21(58 \%)$ & 0.41 \\
\hline \multicolumn{5}{|c|}{ Place of residence on admission } \\
\hline Home & $83(83 \%)$ & $54(84 \%)$ & $29(81 \%)$ & 0.56 \\
\hline Long-term care facility & $17(17 \%)$ & $10(16 \%)$ & $7(19 \%)$ & \\
\hline \multicolumn{5}{|l|}{ Medical history } \\
\hline Smoking history & $80(80 \%)$ & $52(81 \%)$ & $28(78 \%)$ & 0.17 \\
\hline Never smoked & $16(16 \%)$ & $8(13 \%)$ & $8(22 \%)$ & \\
\hline Former smoker & $4(4 \%)$ & $4(6 \%)$ & $0(0 \%)$ & \\
\hline \multicolumn{5}{|l|}{ Active smoker } \\
\hline Hypertension & $63(63 \%)$ & $38(59 \%)$ & $25(69 \%)$ & 0.32 \\
\hline Diabetes mellitus & $22(22 \%)$ & $10(16 \%)$ & $12(33 \%)$ & 0.04 \\
\hline Obesity & $16(16 \%)$ & $12(19 \%)$ & $4(11 \%)$ & 0.32 \\
\hline Cardiovascular disease & $28(28 \%)$ & $13(20 \%)$ & $15(42 \%)$ & 0.02 \\
\hline Chronic respiratory disease ${ }^{a}$ & $12(12 \%)$ & $4(6 \%)$ & $8(22 \%)$ & 0.02 \\
\hline Chronic kidney disease & $15(15 \%)$ & $7(11 \%)$ & $8(22 \%)$ & 0.13 \\
\hline
\end{tabular}

Quantitative variables are expressed as median [interquartile range]; range. Qualitative variables are

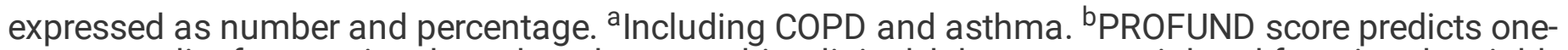
year mortality for a patient based on demographic, clinical, laboratory, social and functional variables, scores between 0 and 30 points and establishes 4 levels of risk of death: low (0-2 points), intermediate (3- 6 points), high (7-10 points) and very high (11-30 points). Abbreviations: HOCG: Hospital d'Olot i Comarcal de la Garrotxa; COPD: chronic obstructive pulmonary disease; ACEl: Angiotensin-converting-enzyme inhibitors; ARB: Angiotensin II receptor blockers 


\begin{tabular}{|c|c|c|c|c|}
\hline & Total & Alive and discharged & Death or ICU & $\mathrm{p}$ value \\
\hline Cirrhosis & $2(2 \%)$ & $1(2 \%)$ & $1(3 \%)$ & 0.68 \\
\hline Malignancy & $14(14 \%)$ & $7(11 \%)$ & $7(19 \%)$ & 0.50 \\
\hline HIV infection & $1(1 \%)$ & $1(2 \%)$ & $0(0 \%)$ & 0.45 \\
\hline Dementia & $11(11 \%)$ & $6(10 \%)$ & $5(14 \%)$ & 0.49 \\
\hline PROFUND score ${ }^{b}$ & $56(56 \%)$ & $43(67 \%)$ & $13(36 \%)$ & 0.03 \\
\hline $0-2$ & $22(22 \%)$ & $11(17 \%)$ & $11(31 \%)$ & \\
\hline $3-6$ & $9(9 \%)$ & $4(6 \%)$ & $5(14 \%)$ & \\
\hline $7-10$ & $13(13 \%)$ & $6(10 \%)$ & 7 (19\%) & \\
\hline \multicolumn{5}{|l|}{$11-30$} \\
\hline \multicolumn{5}{|l|}{ Treatment before admission } \\
\hline ACEI & $30(30 \%)$ & $21(33 \%)$ & $9(25 \%)$ & 0.41 \\
\hline ARB & $8(8 \%)$ & $6(9 \%)$ & $2(6 \%)$ & 0.50 \\
\hline Immunosuppressive drugs & $3(3 \%)$ & $2(3 \%)$ & $1(3 \%)$ & 0.92 \\
\hline Corticosteroids & $6(6 \%)$ & $4(6 \%)$ & $2(6 \%)$ & 0.88 \\
\hline Anticoagulants & $28(28 \%)$ & $12(19 \%)$ & $16(44 \%)$ & 0.006 \\
\hline \multicolumn{5}{|c|}{$\begin{array}{l}\text { Quantitative variables are expressed as median [interquartile range]; range. Qualitative variables are } \\
\text { expressed as number and percentage. }{ }^{2} \text { Including COPD and asthma. bPROFUND score predicts one- } \\
\text { year mortality for a patient based on demographic, clinical, laboratory, social and functional variables, } \\
\text { scores between } 0 \text { and } 30 \text { points and establishes } 4 \text { levels of risk of death: low ( } 0-2 \text { points), } \\
\text { intermediate ( } 3-6 \text { points), high ( } 7-10 \text { points) and very high ( } 11-30 \text { points). Abbreviations: HOCG: } \\
\text { Hospital d'Olot i Comarcal de la Garrotxa; COPD: chronic obstructive pulmonary disease; ACEl: } \\
\text { Angiotensin-converting-enzyme inhibitors; ARB: Angiotensin II receptor blockers }\end{array}$} \\
\hline
\end{tabular}


Table 2

Clinical characteristics, radiological and laboratory findings among 100 patients with COVID-19 admitted to the HOCG

\begin{tabular}{|c|c|c|c|c|}
\hline & Total & Alive & Death or ICU & $\begin{array}{l}\mathrm{p} \\
\text { value }\end{array}$ \\
\hline Number of patients & 100 & 64 & 36 & - \\
\hline \multicolumn{5}{|c|}{ Signs and symptoms on admission } \\
\hline Asymptomatic & $4(4 \%)$ & $4(6 \%)$ & $0(0 \%)$ & 0.13 \\
\hline Cough & $69(69 \%)$ & $44(72 \%)$ & $23(64 \%)$ & 0.41 \\
\hline Fever & $80(80 \%)$ & $50(78 \%)$ & $30(83 \%)$ & 0.67 \\
\hline Dyspnea & $52(52 \%)$ & $29(45 \%)$ & $23(64 \%)$ & 0.07 \\
\hline Fatigue & $59(59 \%)$ & $38(59 \%)$ & $21(58 \%)$ & 0.92 \\
\hline Anorexia & $36(36 \%)$ & $26(41 \%)$ & $10(28 \%)$ & 0.20 \\
\hline Diarrhea & $21(21 \%)$ & $14(22 \%)$ & $7(19 \%)$ & 0.78 \\
\hline Headache & $8(8 \%)$ & $7(11 \%)$ & $1(3 \%)$ & 0.15 \\
\hline Alterations in Smell or Taste & $3(3 \%)$ & $3(5 \%)$ & $0(0 \%)$ & 0.19 \\
\hline Respiratory insufficiency & $64(64 \%)$ & $30(47 \%)$ & $34(94 \%)$ & $\begin{array}{l}< \\
0.001\end{array}$ \\
\hline \multicolumn{5}{|l|}{ Chest radiograph on admission } \\
\hline Normal & $11(11 \%)$ & $10(16 \%)$ & $1(3 \%)$ & 0.04 \\
\hline Bilateral interstitial infiltrates & $65(65 \%)$ & $39(61 \%)$ & $26(72 \%)$ & \multirow[t]{3}{*}{0.59} \\
\hline Alveolar unilateral infiltrate & $12(12 \%)$ & $8(12 \%)$ & $4(11 \%)$ & \\
\hline Other findings & $12(12 \%)$ & $7(11 \%)$ & $5(14 \%)$ & \\
\hline Pleural effusion & $4(4 \%)$ & $3(5 \%)$ & $1(3 \%)$ & 0.64 \\
\hline Thromboembolic disease ${ }^{a}$ & $3(3 \%)$ & $1(2 \%)$ & $2(6 \%)$ & 0.27 \\
\hline \multicolumn{5}{|l|}{ Lung ultrasound $(\mathrm{N}=46)$} \\
\hline Score 0 & $3(6.5 \%)$ & $3(9 \%)$ & $0(0 \%)$ & 0.52 \\
\hline
\end{tabular}

Quantitative variables are expressed as median [interquartile range]. Qualitative variables are expressed as number and percentage. ${ }^{\text {aT }}$ Two pulmonary thromboembolism and one low extremity deep vein thrombosis. Lung ultrasound Scores: Score 0: normal findings. Score 1: The pleura line is continuous and bilateral vertical "B Kerley" lines are visible; Score 2: The pleura line is not continuous and appears thick and irregular; Score 3: Consolidated areas are visible. Abbreviations: HOCG: Hospital d'Olot i Comarcal de la Garrotxa; ICU: intensive care unit. 


\begin{tabular}{|c|c|c|c|c|}
\hline & Total & Alive & Death or ICU & $\begin{array}{l}\mathrm{p} \\
\text { value }\end{array}$ \\
\hline Score 1 & $38(82.6 \%)$ & $27(79 \%)$ & $11(92 \%)$ & \\
\hline Score 2 & $5(10.9 \%)$ & $4(12 \%)$ & $1(8 \%)$ & \\
\hline Score 3 & $0(0 \%)$ & - & - & \\
\hline \multicolumn{5}{|c|}{ Laboratory findings on admission } \\
\hline Hemoglobin (g/dl) & $13[2]$ & $13[2]$ & $13[3]$ & 0.52 \\
\hline White-cell count (per $\mathrm{mm}^{3}$ ) & $7625[4430]$ & $6870[3640]$ & $9090[6650]$ & 0.05 \\
\hline Lymphocyte count (per mm³) & 850 [610] & $1000[560]$ & 815 [715] & 0.24 \\
\hline Platelet count (per $\mathrm{mm}^{3}$ ) & $\begin{array}{l}209,000 \\
{[111,250]}\end{array}$ & $\begin{array}{l}215,500 \\
{[106,750]}\end{array}$ & $\begin{array}{l}191,000 \\
{[121,500]}\end{array}$ & 0.27 \\
\hline \multirow[t]{2}{*}{ D-Dimer (ng/ml) } & 1138 [1184] & 1186 & 1035 [1664] & 0.64 \\
\hline & & [1027] & & \\
\hline Creatinine (mg/dl) & $0.9[0,6]$ & $0.8[0.4]$ & $1.1[0.6]$ & 0.001 \\
\hline C-reactive protein $(\mathrm{mg} / \mathrm{dl})$ & $9.4[12.5]$ & $7.5[9.9]$ & $15.8[20.9]$ & 0.004 \\
\hline Procalcitonin (ng/ml) & $0.1[0.3]$ & $0.08[0.2]$ & $0.36[0.8]$ & $\dot{0.001}$ \\
\hline Creatine kinase (U/L) & $86[160]$ & 68 [67] & 179 [394] & 0.03 \\
\hline $\begin{array}{l}\text { Aspartate aminotransferase } \\
(\mathrm{U} / \mathrm{L})\end{array}$ & 38 [25] & $33[24]$ & $46[67]$ & 0.003 \\
\hline Lactate dehydrogenase (U/L) & $402[264]$ & 366 [196] & 526 [306] & $\begin{array}{l}< \\
0.001\end{array}$ \\
\hline \multicolumn{5}{|c|}{$\begin{array}{l}\text { Quantitative variables are expressed as median [interquartile range]. Qualitative variables are } \\
\text { expressed as number and percentage. a Two pulmonary thromboembolism and one low extremity } \\
\text { deep vein thrombosis. Lung ultrasound Scores: Score 0: normal findings. Score } 1 \text { : The pleura line is } \\
\text { continuous and bilateral vertical "B Kerley" lines are visible; Score 2: The pleura line is not continuous } \\
\text { and appears thick and irregular; Score 3: Consolidated areas are visible. Abbreviations: HOCG: } \\
\text { Hospital d'Olot i Comarcal de la Garrotxa; ICU: intensive care unit. }\end{array}$} \\
\hline
\end{tabular}


Table 3

Prescribed treatment to 100 patients with COVID-19 admitted to the HOCG

\begin{tabular}{|c|c|c|c|c|}
\hline & Total & Alive & $\begin{array}{l}\text { Death or } \\
\text { ICU }\end{array}$ & $\begin{array}{l}\mathrm{p} \\
\text { value }\end{array}$ \\
\hline Number of patients & 100 & 64 & 36 & - \\
\hline \multicolumn{5}{|l|}{ Oxygen therapy FiO2 } \\
\hline FiO2 on admission & 54 & $42(66 \%)$ & $12(33 \%)$ & \multirow[t]{6}{*}{0.001} \\
\hline $21 \%$ & \multirow{2}{*}{$\begin{array}{l}29 \\
(29 \%)\end{array}$} & $14(22 \%)$ & $15(42 \%)$ & \\
\hline $30 \%$ & & $6(9 \%)$ & $1(3 \%)$ & \\
\hline $40 \%$ & $7(7 \%)$ & $1(2 \%)$ & $3(8 \%)$ & \\
\hline $50 \%$ & $4(4 \%)$ & $1(2 \%)$ & $5(14 \%)$ & \\
\hline $100 \%$ & \multicolumn{3}{|l|}{$6(6 \%)$} & \\
\hline Highest $\mathrm{FiO} 2$ during admission & \multirow{2}{*}{$\begin{array}{l}32 \\
(32 \%)\end{array}$} & $28(44 \%)$ & $4(12 \%)$ & \multirow{8}{*}{$\begin{array}{l}< \\
0.001\end{array}$} \\
\hline $21 \%$ & & $20(31 \%)$ & $6(18 \%)$ & \\
\hline $30 \%$ & $\begin{array}{l}26 \\
(27 \%)\end{array}$ & $8(12 \%)$ & $2(6 \%)$ & \\
\hline $40 \%$ & \multirow{2}{*}{$\begin{array}{l}10 \\
(10 \%)\end{array}$} & $2(3 \%)$ & $3(9 \%)$ & \\
\hline $50 \%$ & & $4(6 \%)$ & $17(50 \%)$ & \\
\hline $100 \%$ & $5(5 \%)$ & $2(3 \%)$ & $2(6 \%)$ & \\
\hline \multirow[t]{2}{*}{ High flow oxygen } & $\begin{array}{l}21 \\
(21 \%)\end{array}$ & & & \\
\hline & $4(4 \%)$ & & & \\
\hline Prone positioning & $5(5 \%)$ & $0(0 \%)$ & $5(14 \%)$ & 0.002 \\
\hline \multicolumn{5}{|l|}{ Medical treatment } \\
\hline Only symptomatic & $\begin{array}{l}31 \\
(31 \%)\end{array}$ & $18(28 \%)$ & $13(36 \%)$ & \multirow[t]{2}{*}{0.41} \\
\hline Medication $^{\mathrm{a}}$ & $\begin{array}{l}69 \\
(69 \%)\end{array}$ & $46(72 \%)$ & $23(64 \%)$ & \\
\hline
\end{tabular}

Quantitative variables are expressed as median [interquartile range]. Qualitative variables are expressed as number and percentage. ${ }^{\text {a }}$ Dose regimen: Azithromycin $500 \mathrm{mg}$ QD for one day followed by $250 \mathrm{mg}$ QD for four days; HQC $400 \mathrm{mg}$ BID for one day followed by $200 \mathrm{mg}$ BID for four days. Abbreviations: FiO2: Fraction of inspired oxygen; HCQ: hydroxychloroquine; Lopinavir/r: lopinavir/ritonavir; QD: once a day; BID: two times a day. 


\begin{tabular}{|c|c|c|c|c|}
\hline & Total & Alive & $\begin{array}{l}\text { Death or } \\
\text { ICU }\end{array}$ & $\begin{array}{l}p \\
\text { value }\end{array}$ \\
\hline \multirow{3}{*}{$\begin{array}{l}\text { Azithromycin } \\
\text { HCQ + azithromycin } \\
\text { HCQ + azithromycin + Lopinavir/r }\end{array}$} & $2(3 \%)$ & $0(0 \%)$ & $2(9 \%)$ & \multirow[t]{3}{*}{0.04} \\
\hline & $\begin{array}{l}66 \\
(96 \%)\end{array}$ & $\begin{array}{l}46 \\
(100 \%)\end{array}$ & \multirow{2}{*}{$\begin{array}{l}20(87 \%) \\
1(4 \%)\end{array}$} & \\
\hline & $1(1 \%)$ & $0(0 \%)$ & & \\
\hline $\begin{array}{l}\text { Days from the onset of symptoms to start of } \\
\text { treatment }\end{array}$ & $9[4]$ & $9[4]$ & 7 [7] & 0.08 \\
\hline Intravenous antibiotics & $\begin{array}{l}26 \\
(26 \%)\end{array}$ & $13(20 \%)$ & $13(36 \%)$ & 0.08 \\
\hline Glucocorticoids & $\begin{array}{l}12 \\
(12 \%)\end{array}$ & $6(9 \%)$ & $6(17 \%)$ & 0.28 \\
\hline $\begin{array}{l}\text { Quantitative variables are expressed as media } \\
\text { expressed as number and percentage. }{ }^{\text {a Dose }} \text { ro } \\
\text { by } 250 \mathrm{mg} \text { QD for four days; HQC } 400 \mathrm{mg} \text { BID } \\
\text { Abbreviations: FiO2: Fraction of inspired oxyg } \\
\text { lopinavir/ritonavir; QD: once a day; BID: two tir }\end{array}$ & $\begin{array}{l}\text { dartile ro } \\
\text { Azithror } \\
\text { day follc } \\
\text { hydroxy }\end{array}$ & $\begin{array}{l}\text {. Qualitat } \\
\text { n } 500 \mathrm{mg} \\
\text { by } 200 \mathrm{~m} \\
\text { roquine; L }\end{array}$ & $\begin{array}{l}\text { D for one da } \\
\text { BID for fou } \\
\text { pinavir/r: }\end{array}$ & $\begin{array}{l}\text { llowed } \\
\text { ls. }\end{array}$ \\
\hline
\end{tabular}

During hospitalization, 26 patients $(26 \%)$ died and $10(10 \%)$ were transferred to the ICU. The outcome in the $\mathrm{UCl}$ was as follows: 3 patients died, 4 were discharged at home and 4 remain admitted. After a median length of stay of 7 days, the remaining 64 patients (64\%) were discharged at home with no readmissions during the study period. Patients with more advanced age, with more comorbidities (diabetes mellitus, cardiovascular and respiratory chronic diseases) and a higher PROFUND score at baseline, presenting with respiratory insufficiency or radiographic abnormalities or more prominent laboratory abnormalities, and those requiring higher oxygen concentrations, had more severe disease (including death or ICU admission).

\section{Discussion}

To our knowledge, this study represents the first case series of sequentially hospitalized patients with laboratory-confirmed COVID-19 from a community hospital and also from Spain.

In comparison with other series of hospitalized patients, our study includes and represents older patients, with a median age of 75 years and more than a third over 80 years old. Series from China, United States and Italy included younger patients ranging from 47 to 55 in China [2] and from 61 to 64 in United States and Italy [7-11].

Similar to these previous series, our patients had many comorbidities (specially arterial hypertension, diabetes mellitus and cardiovascular diseases) and a low proportion of smokers, chronic respiratory diseases or HIV infection [2,7-11]. The clinical and laboratory presentation were also similar to the already described, and, unlike other centres, we performed few chest CT scans (in part, to avoid 
transferring patients outside the isolation area) and more LUS. In our opinion, LUS can be very useful in characterizing lung involvement of COVID-19 even when chest radiograph is normal [6].

Finally, we found a high in-hospital mortality rate (26\%). This is clearly higher than those reported at the start of the pandemic in China (1.4-11\%) [2] and the first communications from the United States (10$21 \%$ in New York and $15.6 \%$ in California) [8-9]. The old population and high comorbidity of our patients may explain, in part, this high mortality. We believe that mortality could have been even higher if more patients had been admitted from long-term care facilities ( $17 \%$ in the present study) were mortality rates are even higher [3].

Apart from age and comorbidities we have found other variables associated with more severe disease: respiratory insufficiency or radiographic abnormalities at presentation, more prominent laboratory abnormalities, and requiring higher oxygen concentrations. We have also found that those patients treated with hydroxychloroquine and azithromycin had a better prognosis, but this finding should be interpreted with caution. Treatment assignation was not randomized, and it was prescribed according to regional protocols and at treating physician discretion and after consent of the patient.

The main strength of this study is that it is prospective (including all consecutively hospitalized patients) and that it offers unpublished information so far, including older patients, from a community (nonuniversity) hospital and from Spain. The main limitation of this study is that the data only represent a single centre in a rural region of Spain, so the findings cannot be generalized. More studies from Spain and other European countries are necessary to verify the clinical characteristics, in-hospital mortality rates and prognostic factors of COVID-19.

\section{Conclusions}

In this case series of patients with laboratory confirmed COVID-19 admitted to a community hospital in Spain, the majority were old patients with comorbidities and in-hospital mortality was high (26\%).

\section{Abbreviations}

COVID-19: coronavirus disease 2019; CT: computed tomography; HOCG: Hospital de Olot i comarcal de la Garrotxa; ICU: Intensive Care Unit; IQR: interquartile range; LUS: lung ultrasound; WHO: World Health Organization

\section{Declarations}

\section{Ethics approval:}

the Ethics Committee of the "Hospital Universitari Dr. Josep Trueta, Girona (Spain)" approved the study protocol. 


\section{Consent to participate}

informed consent was obtained from all participating subjects

\section{Availability of data and material:}

All data generated or analysed during this study are included in this published article. In addition, the datasets used and/or analysed during the current study are available from the corresponding author on reasonable request.

\section{Conflicts of interest:}

the authors report no conflict of interest

\section{Funding:}

no funding was received

\section{Authors' contributions:}

all authors made substantial contributions to this work: 1.- Conception and design of the study: all authors; 2.- Acquisition of data: JCT, ER, CW, AS and GB; 3.- Statistical analysis: JCT; 4.- Analysis and interpretation of data: all authors; 5.- Article draft: JCT; 6.- Article revising and final approval: all authors.

\section{Acknowledgments:}

we thank Mercè Espejo and Montse Invernó for their administrative support and also Dr. Jose $\mathrm{M}^{\mathrm{a}}$ Miró for his always wise advice.

\section{References}

1. - Spiteri G, Fielding J, Diercke M, et al. First cases of coronavirus disease 2019 (COVID-19) in the WHO European Region, 24 January to 21 February 2020. Euro Surveill. 2020;25:2000178. doi:10.2807/1560-7917.ES.2020.25.9.2000178.

2. - Guan WJ, Ni ZY, Hu Y, et al. Clinical Characteristics of Coronavirus Disease 2019 in China [published online ahead of print, 2020 Feb 28]. N Engl J Med. 2020 NEJMoa2002032. doi:10.1056/NEJMoa2002032.

3. - McMichael TM, Currie DW, Clark S, et al. Epidemiology of Covid-19 in a Long-Term Care Facility in King County, Washington [published online ahead of print, 2020 Mar 27]. N Engl J Med 2020 NEJMoa2005412. doi:10.1056/NEJMoa2005412. 
4. - Grasselli G, Zangrillo A, Zanella A, et al. Baseline Characteristics and Outcomes of 1591 Patients Infected With SARS-CoV-2 Admitted to ICUs of the Lombardy Region, Italy [published online ahead of print, 2020 Apr 6]. JAMA 2020 e205394. doi:10.1001/jama.2020.5394.

5. - Bernabeu-Wittel M, Ollero-Baturone M, Moreno-Gaviño L, et al. Development of a new predictive model for polypathological patients. The PROFUND index. Eur J Intern Med. 2011;22:311-7. doi:10.1016/j.ejim.2010.11.012.

6. - Soldati G, Smargiassi A, Inchingolo R, et al. Proposal for International Standardization of the Use of Lung Ultrasound for Patients With COVID-19: A Simple, Quantitative, Reproducible Method [published online ahead of print, 2020 Mar 30]. J Ultrasound Med. 2020. 10.1002/jum.15285. doi:10.1002/jum.15285.

7. - Goyal P, Choi JJ, Pinheiro LC, et al. Clinical Characteristics of Covid-19 in New York City [published online ahead of print, 2020 Apr 17]. N Engl J Med 2020 NEJMc2010419. doi:10.1056/NEJMc2010419.

8. - Richardson S, Hirsch JS, Narasimhan M, et al. Presenting Characteristics, Comorbidities, and Outcomes Among 5700 Patients Hospitalized With COVID-19 in the New York City Area [published online ahead of print, 2020 Apr 22]. JAMA 2020 e206775. doi:10.1001/jama.2020.6775.

9. - Myers LC, Parodi SM, Escobar GJ, Liu VX. Characteristics of Hospitalized Adults With COVID-19 in an Integrated Health Care System in California [published online ahead of print, 2020 Apr 24]. JAMA 2020 e207202. doi:10.1001/jama.2020.7202.

10. - Bhatraju PK, Ghassemieh BJ, Nichols M, et al. Covid-19 in Critically III Patients in the Seattle Region - Case Series [published online ahead of print, 2020 Mar 30]. N Engl J Med 2020 NEJMoa2004500. doi:10.1056/NEJMoa2004500.

11. - Grasselli G, Zangrillo A, Zanella A, et al. Baseline Characteristics and Outcomes of 1591 Patients Infected With SARS-CoV-2 Admitted to ICUs of the Lombardy Region, Italy [published online ahead of print, 2020 Apr 6]. JAMA. 2020;323:1574-81. doi:10.1001/jama.2020.5394.

\section{Figures}




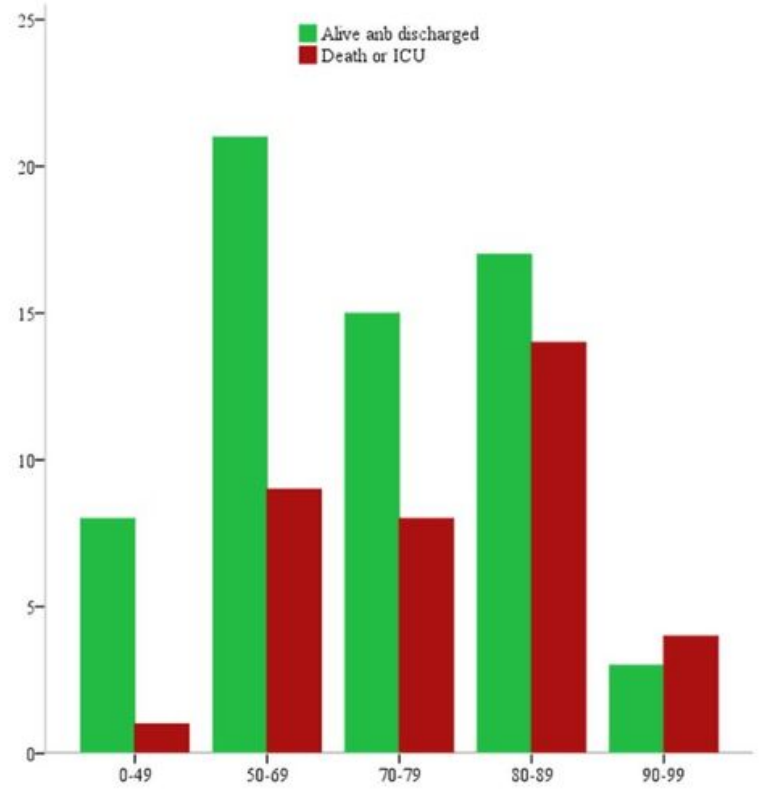

Figure 1

Age distribution by groups and prognosis 